\title{
Læreres profesjonsetikk i fokus
}

\author{
Av Førsteamanuensis EsPen SCHJETne (f. 1968) espen.schjetne@hiof.no, \\ førsteamanuensis HiLde Afdal (f. 1968) hilde.afdal@hiof.no, \\ førsteamanuensis NinA JoHANNESEN (f. 1970)nina.johannesen@hiof.no, \\ førsteamanuensis TRINE ANKER ( $f$. 1969)trine.anker@mf.noog \\ professorGEIR AFDAL (f. 1962)geir.afdal@mf.no.
}

Lærere og ledere i barnehage og skole har talt. Profesjonsetikk er særdeles viktig, og følgende begrunnelser blir gitt. For det først er profesjonsetikken viktig for å utvikle profesjonell refleksjon, for det andre for å begrunne profesjonelle handlinger, og sist, men ikke minst, for ansvarliggjøring i det offentlige rom.

- Profesjonell refleksjon:

Vi ønsker å få profesjonsetikken inn $i$ «autopiloten» - ikke ureflektert - ikke automatikk, men inn i måten å tenke og reflektere på. Det handler ikke bare om å gjøre - det handler om å reflektere over valg, på forhånd, rett for og etterpå. Det handler om begrunnelser $i$ hverdagen, selvstendige vurderinger, få den inn i bevisstheten hos alle.

Vi ønsker øvelse i refleksjon og vi ønsker å skape en refleksjonskultur på vår arbeidsplass. Vi ønsker å diskutere profesjonsetiske utfordringer. Vi står sterkere som profesjonsutøver hvis vi har diskutert lignende situasjoner før?

- Begrunne handlinger:

Vi har behov for profesjonsetikken for å begrunne handlinger. Begrunne hvorfor vi tar akkurat denne avgjørelsen? Er det fordi den er i tråd med mandatet? Er det ifølge avtaleverket? Er det den enkleste løsningen? $V i$ vil velge ut noen avgjørelser og utvikle gode begrunnelser.

- Ansvarliggjøring:

Profesjonsetikk handler om å vere ansvarlig og det ønsker vi å videreutvikle: Ta ansvar for vår yrkesutøvelse, vår kommunikasjon og reflektere i et ansvarlig rom.

Dette er uttalelser fra lærere og ledere i skoler og barnehager som har vært med i pilotprosjekter på sin arbeidsplass knyttet til Utdanningsforbundets implementering av Lærerprofesjonens etiske plattform (Utdanningsforbundet, 2012) ${ }^{1}$. Hovedformålet med Plattformen var og er ifølge Utdanningsforbundet ikke primært å presentere et sett av regler for profesjonsutøvelsen. Den er snarere tenkt som et (diskusjons)verktøy for lærere og andre aktører i ulike utdanningspraksiser.

\section{ETIPP}

Etikk i profesjonell praksis (EtiPP) var et følgeforskningsprosjekt knyttet til implementeringen av Plattformen (Afdal, Johannesen, Schjetne, Anker, \& Afdal, 2015), og noen av hovedfunnene i prosjektet presenteres i denne lille artikkelen. For mer detaljerte ana-

1 Heretter omtalt som «Plattformen» 
lyser og en mer utfyllende drøfting se Afdal et al. (2015). Prosjektet hadde fem gjennomgående fokusområder:

1 Kjennskap til Plattformens innhold og implementeringsprosessen

2 Konseptualisering (Hva er egentlig profesjonsetikk?)

3 Kollektive praksiser (Hvordan gjøres profesjonsetikk i lærerprofesjonene?)

4 Profesjonsetikk og profesjonsbetingelser (Profesjonsetikk, politiske og strukturelle rammebetingelser)

Kvalitative og kvantitative data ble samlet $\mathrm{i}$ ulike deler av landet. Intervjuer av, og spørreundersøkelse blant lærerutdannere, lærerstudenter, lærere og ledere og eiere i barnehage og skole ble gjennomført. Prosjektet baserte seg på en vid forståelse av etikk, som spørsmål om det rette og det gode, og trakk veksler på både filosofisk etikk og empiriske studier av etiske praksiser. Profesjonsetikk blir dermed spørsmål om det gode og det rette i pedagogiske praksiser og utdanning. Profesjonsetikk dreier seg om profesjonsutøverens skjønn, men også om de pedagogiske og politiske vilkår for utøvelse av et slikt skjønn.

\section{TYKK VERSUS TYNN}

\section{PROFESIONSETIKK}

Når de ulike aktørene blir spurt om hva profesjonsetikk er og omfatter, gir de aller fleste uttrykk for det som kan betegnes som en tykk forståelse: Profesjonsetikk er et perspektiv ved all pedagogisk praksis, sier de. Samtidig viser analysene et paradoks. Når de snakker om hva profesjonsetikk mer konkret dreier seg om, er det ikke alt, men noen ganske få, avgrensede temaer og områder som trer frem, for eksempel forholdet barn voksen eller de mange daglige dilemmaene som kan dukke opp i profesjonell praksis. Mye av den pedagogiske praksisen blir ikke gjort til gjenstand for deres profesjonsetiske analyse. Spørsmålet er hvordan dette paradokset kan forstås.

Det er helt klart at alle grupper i materialet ikke skiller mellom profesjonsetikk på den ene side og etiske aspekter ved undervisning og pedagogisk praksis i videre forstand på den andre. Profesjonsetikk dreier seg ikke bare om avgrensede dilemmaer, det dreier seg også om å ha et etisk blikk på potensielt alt som skjer i barnehagen og skolen. Profesjonsetikk handler ikke kun om å handle rett i situasjoner, men om å være en god lærer og være med på å utvikle en god barnehage og skole.

Samtidig er det enkeltsituasjonene og casene lærerne trekker frem når de forteller hva profesjonsetikk er i praksis. Abstrakt og teoretisk profesjonsetikk har begrenset verdi som hjelp i praktiske situasjoner, hevder lærerne. Videre snakker de lettere om profesjonsetikk på visse områder enn andre. Aktørene reflekterer profesjonsetikk mer knyttet til sosial dannelse enn til fag. Lærerne og lederne snakker mer om profesjonsetikk i forbindelse med tillit til elevene enn hvorfor og hvordan man skal undervise i eksempelvis middelalderen. Profesjonsetikk går godt sammen med ulike metodiske programmer (som Pals og Zero), hevder de fleste, men de har problemer med å identifisere profesjonsetiske aspekter ved dem.

DET PROFESJONSETISKE SPRÅKET Hva er grunnen til det? Vi vil hevde at det ikke er fordi aktørene har en tynn forståelse av profesjonsetikk, men fordi de har et lite utviklet profesjonsetisk språk. Et gjennomgående funn i lærerutdanningene er at profesjonsetikk forstås som viktig, men vag - både hos studenter og pedagogikklærere. Når det er slik i lærerutdanningen, er det ikke mer- 
kelig at lærerne har problemer i praksis. Det skal sies at det er en forskjell mellom skole og barnehage. I barnehagen har vi funnet mer kollektiv profesjonsetisk refleksjon - over for eksempel hva det vil si å være respektfull og hva medvirkning betyr i praksis. Det må også understrekes at våre funn er ikke entydige. Det er for eksempel ulikt hvordan det arbeides med profesjonsetikk i lærerutdanningene. Samtidig er bildet på tvers av et ganske omfattende materiale ganske entydig på dette punktet. Og mange av aktørene reflekterer over sitt eget mangelfulle profesjonsetiske språk. (For mer utfyllende analyser knyttet til lærerutdanning se Schjetne, Afdal, Anker, Johannesen og Afdal (2016).)

\section{PROFESJONSETIKKENS \\ BAKGRUNN}

Et gjennomgående funn er at de ulike aktørene bruker ulike teoretiske og praktiske redskaper i sin konstruksjon av profesjonsetikk, men at noen av disse redskapene befinner seg i forgrunnen og noen i bakgrunnen.

To av de redskapene som plasseres i bakgrunnen, er en instrumentell konsekvensetisk logikk på den ene side og regler og pliktlogikk på den andre. Dette betyr altså ikke at disse måtene å reflektere og vurdere på er fraværende, men at de ikke spiller en hovedrolle. For eksempel er forpliktelse og plikt mer fremtredende i relasjon til samfunnsmandat enn i lærernes nære og hverdagslige relasjoner.

Konsekvensetikkens og pliktetikkens birolle kan beskrives som noe overraskende. En resultatorientert og instrumentell logikk ligger innebakt i en markeds- og konkurranseorientering av utdanning (Ball, 2008). Materialet tyder på at aktørene har en annen etisk logikk enn førende utdanningsdiskurser, og at den ikke er hovedsakelig instrumentell.
Regler, normer og rettigheter har selvfølgelig en rolle i de ulike pedagogiske institusjonene, men de dominerer ikke. Ofte blir regler forstått innenfor en dydsetisk ramme. Den gode lærer bruker regler, men ikke teknisk eller absolutt, hun bruker dømmekraft. Disse funnene er overraskende fordi mye pedagogisk profesjonsetisk forskning og teori setter prinsipper og normer i sentrum. I den profesjonsetiske faglitteraturen er dilemmaer og valg mer fremtredende enn hos aktørene i vår undersøkelse. Profesjonsetiske koder har tradisjonelt også vært dominert av prinsipper og normer for profesjonell atferd.

Samtidig er ikke dette hele historien når det gjelder vårt materiale. Et viktig funn er at det pliktetiske språket er mer fremtredende i lærernes relasjon til samfunn og politikk enn i deres nære relasjoner til barn, elever og kolleger.

Relasjoner er selvfølgelig vesentlige i læreres profesjonsetikk, og samtlige påpeker relasjonen til det enkelte barn og den enkelte elev som primær. Samtidig er disse relasjonene mer å forstå som felt og ansvarsforhold der læreren utfører sin profesjonsetikk, enn etiske ressurser. Med noen unntak bestemmes etikken i liten grad av den andres grunnleggende forskjellighet, eller at den andre legger sitt liv i lærerens hånd. Det betyr at eleven og barnet blir mer objekt for lærerens profesjonsetikk enn et subjekt som kan gi læreren profesjonsetiske innsikter.

\section{PROFESJONSETIKKENS FORGRUNN}

I profesjonsetikkens forgrunn står lærerrollen, lærerens kvaliteter, dømmekraft, holdninger, refleksjon og handlingsberedskap. I materialet er profesjonsetikken knyttet til den enkelte lærer mer enn til prinsipper, konsekvenser og relasjoner. Profesjonsetikken er 
knyttet nært til tanken om den gode enkeltlærer.

Et gjennomgående funn er at den gode enkeltlærer forstås både som personlige og som rollebestemte kvaliteter. På den ene side kan en lærer ikke skille mellom det personlige og lærerrollen, hevder informantene. Man kan ikke uttrykke innvandrerfiendtlige holdninger som privatperson og samtidig ha tillit hos eleven som lærer. Man kan ikke skille mellom det personlige og lærerrollen, men man må skjelne og forhandle mellom dem. Lærerrollen har en dobbel kollektiv forpliktelse. For det første har man som lærer et samfunnsmandat og står til ansvar overfor en formålsbestemmelse av barnehage og skole. For det andre er man som lærer representant for hele lærerstanden og lærerprofesjonen, man er mer enn en person og et individ. Det profesjonsetiske består dermed i en kontinuerlig utvikling av personlige holdninger. Å være lærer er å være i forandring. Men det består også i en avklaring av ens kollektive rolle som lærer, en avklaring som i en praktisk hverdag forhandles frem i interaksjon med andre lærere.

\section{SAMFUNNSBETINGELSER OG ARBEIDET MED PROFESJONS- ETIKK}

Når det gjelder samfunnsbetingelser for lærernes profesjonsetikk, er funnene sammensatte. På den ene side sier de aller fleste at læreres profesjonsetikk også omfatter samfunnsforhold. På den andre side reflekterer aktørene i liten grad konkret hvordan disse setter betingelser for og slår inn i lærerpraksis. Kritiske analyser av samfunnsbetingelser og utdanningspolitikk forstås som individuelle spørsmål, noe den enkelte lærer må ta stilling til som privatperson, og i liten grad som et profesjonsanliggende. Videre forstås kritikk som personlige meninger og spørsmål om politisk aktivisme mer enn som faglige analyser.

Lærerne og lederne preges i stor grad av lojalitet i betydningen lydighet overfor politiske myndigheter. I praksis blir dermed samfunnsspørsmål, samfunnsbetingelser og utdanningspolitikk fritatt for profesjonsetiske analyser. Videre blir samfunnsbetingelsene og de utdanningspolitiske føringene forstått som gitt. I stor grad unndras disse forholdene faglig analyse. Det faglige og profesjonsetiske fokus er på de nære relasjoner. Dermed blir det i stor grad usynlig hvordan de ytre betingelsene slår inn og er medbestemmende i eksempelvis en lærer-elev relasjon. Videre forstår aktørene samfunnsbetingelser hovedsakelig som planverk og forskrifter - og mindre som de betydelige og systematiske forventninger til resultater som medier, foreldre, politikere og andre samfunnsaktører uttrykker. Samfunnskravet om at skoler og lærere skal «levere», gjøres i liten grad til objekt for faglige analyser. Vi argumenterer her ikke mot læreres lojalitet overfor deres samfunnsmandat, men hevder at samfunnsmandatet og samfunnsbetingelsene i liten grad gjøres til gjenstand for faglig analyse. Slike analyser er helt nødvendige for lærernes profesjonsetiske vurderinger.

I forlengelsen av dette vil vi påpeke ytterligere to momenter. Det første gjelder forståelsen av kritikk. Samfunnsanalyser er ikke det samme som politisk aktivisme. Samfunnsanalyser er verken mer eller mindre kritiske enn analyser av pedagogiske praksiser i skole og barnehage. Det viktige er forståelse av sammenhengen mellom samfunnsbetingelser og hverdagslig profesjonell praksis. Kritikk av samfunnsbetingelser må eventuelt skje på grunnlag av faglige analyser. Det andre gjelder forholdet mellom utdannings- 
politikk og pedagogisk faglighet. Vi vil hevde at det er avgjørende for en pedagogisk profesjonalitet at lærere har en utviklet faglighet og faglig identitet som er noe annet enn deres samfunnsmandat og samfunnslojalitet. Gjennomgånde i materialet understrekes den politisk bestemte fagligheten mer enn lærernes egen pedagogiske og annen faglige identitet. Den pedagogiske fagligheten knyttes mer til å gjennomføre den politisk bestemte fagligheten enn til aktive forhandlinger mellom sterk faglig identitet på den ene side og samfunnsoppdrag på den andre.

Vår samlede og entydige konklusjon er at pedagogisk profesjonsetikk er viktigere enn noen gang. Barnehage- og grunnskolelærere står i et betydelig krysspress, der de må forhandle mange ulike og motstridende hensyn. Det er helt avgjørende at de viser at barn, elever, foreldre, politikere og media kan ha tillit til lærere, men at de også må ha tillit for å kunne gjøre en faglig og etisk god jobb. Videre er det avgjørende at lærere synliggjør at etisk og faglig ansvar («responsibility») i barnehage og skole er videre og mer grunnleggende enn teknisk ansvar («accountability») for lærernes profesjonsetiske praksis.

\section{LITTERATUR}

Afdal, H., Johannesen, N., Schjetne, E., Anker, T., \& Afdal, G. (2015). Etikk i profesjonell praksis: Et følgeforskningsprosjekt knyttet til Utdanningsforbundets implementering av Lærerprofesjonens etiske plattform. Oppdragsrapport 2015:5, ISBN 82-78-25442-7.

Ball, S. J. (2008). The education debate. Bristol: The Policy Press.

Schjetne, E., Afdal, H. W., Anker, T., Johannesen, N., \& Afdal, G. (2016). Empirical Moral Philosophy and Teacher Education. Ethics and Education, 11 (1).

Utdanningsforbundet. (2012). Lærerprofesjonens etiske plattform. https:// www.utdanningsforbundet.no/upload/ Publikasjoner/Profesjonsetikk/Plattformen/ L\%C3\%A6rerprof_etiske_plattform_A3 bokmal_hvit_rev_131114.pdf. 